\title{
Milk Authentication: Stable Isotope Composition of Hydrogen and Oxygen in Milks and Their Constituents
}

\author{
Staša Hamzić Gregorčič ${ }^{1,2}$, Doris Potočnik ${ }^{1,2}$, Federica Camin ${ }^{3,4}$ and Nives Ogrinc ${ }^{1,2, *}$ \\ 1 Department of Environmental Sciences, Jožef Stefan Institute, Jamova 39, 1000 Ljubljana, Slovenia; \\ stasa.gregorcic@ijs.si (S.H.G.); doris.potocnik@ijs.si (D.P.) \\ 2 Jožef Stefan International Postgraduate School, Jamova 39, 1000 Ljubljana, Slovenia \\ 3 Department of Food Quality and Nutrition, Research and Innovation Centre, Fondazione Edmund Mach, \\ via Mach 1, 38010 San Michele all'Adige, Italy; federica.camin@fmach.it \\ 4 Center Agriculture Food Environment (C3A), University of Trento, via Mach 1, 38010 San Michele \\ all'Adige (TN), Italy \\ * Correspondence: nives.ogrinc@ijs.si; Tel.: +386-1-588-5387
}

Academic Editor: Derek J. McPhee

Received: 15 July 2020; Accepted: 1 September 2020; Published: 2 September 2020

\begin{abstract}
This paper summarises the isotopic characteristics, i.e., oxygen and hydrogen isotopes, of Slovenian milk and its major constituents: water, casein, and lactose. In parallel, the stable oxygen isotope ratios of cow, sheep, and goat's milk were compared. Oxygen stable isotope ratios in milk water show seasonal variability and are also ${ }^{18} \mathrm{O}$ enriched in relation to animal drinking water. The $\delta^{18} \mathrm{O}_{\text {water }}$ values were higher in sheep and goat's milk when compared to cow milk, reflecting the isotopic composition of drinking water source and the effect of differences in the animal's thermoregulatory physiologies. The relationship between $\delta^{18} \mathrm{O}_{\text {milk }}$ and $\delta^{18} \mathrm{O}_{\text {lactose }}$ is an indication that even at lower amounts $(>7 \%)$ of added water to milk can be determined. This procedure once validated on an international scale could become a reference method for the determination of milk adulteration with water.
\end{abstract}

Keywords: milk; adulteration; water addition; oxygen stable isotopes; lactose

\section{Introduction}

After the melamine milk powder incident in China in 2008 the adulteration of milk and dairy products highlighted the need for greater transparency in the food chain, guarantees surrounding food quality and safety and the development of methods for determining the authenticity of dairy products [1]. Although milk is a frequent target for fraud [2], available knowledge and data about methods for the prevention or mitigation of the fraud issue is still limited. In order to assure the authenticity of milk, one requires a deep understanding of the characteristics of authentic milk. In response, scientists have developed new analytical techniques and strategies [3,4], which will assist milk producers and suppliers in the detection and prevention of milk fraud.

When milk is diluted with water, its nutritional value decreases and in addition chemicals are added to compensate the density and the colour after dilution, thus posing a potential risk to human health [2]. Further, there are very strong economic arguments of minimizing the allowed amount of added water to milk, since the price of milk is based on milk solids contents. The processing of milk also provides an opportunity for producers to add water beyond the acceptable limits in preserved milk, which is illegal. Since it is not compulsory to state the amount of added water on the label, some companies take advantage of this legal loophole. 
Several methods to detect adulterants in milk exists including measurement of freezing point depression, electrical admittance spectroscopy, single-frequency conductance measurements, digital image chromatography, ultraviolet (UV) visible light spectroscopy, and enzyme linked immunosorbent assay [5-7]. Determining the milk water content is typically performed using traditional methods such as by measuring changes in freezing point of the milk or changes in the refraction of light through the whey component of milk after precipitation and removal of the casein and fat components using either acetic acid or copper sulfate. Current methods can be classed as direct contact methods, which are not reliable for making continuous measurements. Other methods involve separating the water from milk solids and then quantifying the amount of water by weight or volume- these techniques, although accurate, are time-consuming and expensive. Among modern techniques near infrared (NIR) spectroscopy has proved to be a fast non-destructive method for food safety evaluation and control [8-11], and can be also used to detect water and its content in milk [10]. The main drawback is that the milk has a near-infrared absorption spectrum similar to that of the water [9]. Time-domain nuclear magnetic resonance (TD-NMR) method has been used for quantification of fat and water content in cheese [12] and to identify several adulterants in milk such as water, whey, synthetic milk, synthetic urine and hydrogen peroxide [13]. Although the method is widely used in dairy studies, it has some restrictions, especially in samples with either low water or low-fat concentration $(<5 \% v / v)$.

The use of stable isotopes of light elements is an approach of a grown interest in terms to discover possible commercial fraud [14]. Several studies have demonstrated that stable oxygen isotope ratios ( $\delta^{18} \mathrm{O}$ values) has been successfully applied to detect illegal watering of different types of food matrices such as wine [15], fruit juices [16], and concentrated spirits [17]. $\delta^{2} \mathrm{H}$ and $\delta^{18} \mathrm{O}$ values in water can provide key information on water origins (e.g., local precipitation, groundwater), climate (ambient temperatures during condensation and precipitation) and the degree of evapotranspiration [18-20]. The relationship between $\delta^{2} \mathrm{H}$ and $\delta^{18} \mathrm{O}$ values in the hydrosphere throughout the continents known as the meteoric water line ( $\mathrm{MWL} ; \delta^{2} \mathrm{H}=8 \delta^{18} \mathrm{O}+10$ ) was first defined by Craig [21]. Besides the 'latitude' effect, there is a 'continental' effect due to the distance from the sea, related to the vapour masses moving over continents leading to the lower $\delta^{2} \mathrm{H}$ and $\delta^{18} \mathrm{O}$ values in precipitation (mean decrease of $-2.8 \% \mathrm{o} / 1000 \mathrm{~km}$ from the coast). Moreover, different altitudes inland also lead to decrease in $\delta^{2} \mathrm{H}$ and $\delta^{18} \mathrm{O}$ values in precipitation since at higher altitude there is isotopically lighter vapour. Finally, another variation in $\delta^{2} \mathrm{H}$ and $\delta^{18} \mathrm{O}$ values can occur due to seasonal trends; during summer the enrichment in ${ }^{2} \mathrm{H}$ and ${ }^{18} \mathrm{O}$ in precipitation, especially inland, occurs.

The sources of $\mathrm{H}$ and $\mathrm{O}$ in animals are drinking water, food, food water and in case of $\mathrm{O}$ also molecular $\mathrm{O}_{2}$ [22]. Groundwater the main source of animal drinking water has an isotopic composition depending on geographical factors such as altitude, latitude and distance from the sea, but not on the season. In plants, the main components of feed, the isotopic composition of water are positive relative to those of the corresponding soil water. Furthermore, the $\delta^{18} \mathrm{O}$ values in plants reflect evaporative enrichment transpiring leaves and isotopic exchange between plant water and organic molecules [23,24]. The average $\delta^{18} \mathrm{O}$ value of the body water of most domestic animals is about $3 \pm 1 \%$ o more positive than that of the drinking water [25]. Consequently, the enrichment in ${ }^{2} \mathrm{H}$ and ${ }^{18} \mathrm{O}$ was observed also in milk where the metabolism, and isotopic fractionation during milk synthesis cause additional isotopic fractionation. Overall, the isotopic composition of milk depends on species, drinking, and respiration rates [25], season, farm conditions, breed, and the physiological condition of the animal [26,27]. Dairy animal species with different thermoregulatory physiology should have different water isotope fractionation in body fluids, which is related to evaporation, as vapour is more depleted in heavy isotopes than other body fluids [28,29]. Further, goat milk has a higher proportion of calcium compared to cow milk, which is linked to the higher metabolic rate of the smaller animal [30]. Likewise, according to Bryant and Froelich [30] and Podlesak et al. [31], body surface area relative to body mass makes a mammal prone to water loss via evaporation. A relationship between $\delta^{18} \mathrm{O}$ in milk water and the season was reported by Kornexl et al. [32], due to seasonal changes in the $\delta^{18} \mathrm{O}$ 
of forage plants, as well as in the body of the animal, linked to evapotranspiration. $\delta^{2} \mathrm{H}$ and $\delta^{18} \mathrm{O}$ stable isotopes in milk were also used to detect its geographical origin, due to the relationship between the isotopic signature of milk and that of the drinking water of regions located at different latitudes and/or altitudes [33,34]. More recently, the exchange of $\mathrm{H}$ and $\mathrm{O}$ between organic molecules and animal's body water due to metabolism and biosynthesis were studied. The results suggested that $\mathrm{H}$ isotopes carry a signature related to dietary habits of the animal, while $\mathrm{O}$ isotopic signature reflects more animal's physiological water balance [35].

Our paper introduces the concept of using $\delta^{2} \mathrm{H}$ and $\delta^{18} \mathrm{O}$ measurements in the milk and its constituents as a natural isotopic toolbox to provide information about the sources of water in milk and to detect possible adulteration of milk with water. Thus, the main objectives of our study were to: (1) identify the differences in the $\delta^{18} \mathrm{O}$ value in milk according to the season, region and animal species; (2) identify the correlations between $\delta^{18} \mathrm{O}$ values in milk and drinking water; and (3) to test the use of $\delta^{18} \mathrm{O}$ values in lactose as an internal standard for the detection of water addition.

\section{Results and Discussion}

\subsection{Stable Isotope Composition of Milk and Casein: Year, Season, Region and Species Variability}

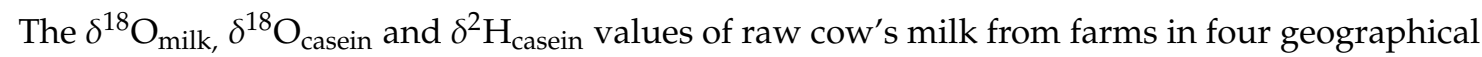
regions in Slovenia: Alpine, Dinaric, Pannonian, and the Mediterranean, broken down according to season and year of production are presented in Table S1 (Supplementary Material). The $\delta^{18} \mathrm{O}_{\text {milk }}$ values in collected cow milk samples $(n=319)$, produced between 2012 and 2015 , ranged from $-9.2 \%$ o to $-0.04 \%$ o (Figure $1 \mathrm{a}-\mathrm{d}$ ). The $\delta^{18} \mathrm{O}_{\text {casein }}$ values ranged from $8.8 \%$ o to $14.6 \%$, and the $\delta^{2} \mathrm{H}_{\text {casein }}$ values were from $-150 \%$ o to $-100 \%$ o.

a)

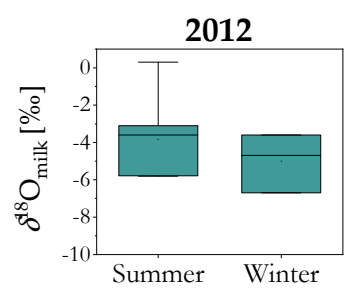

b)

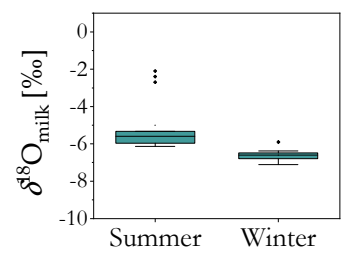

c)

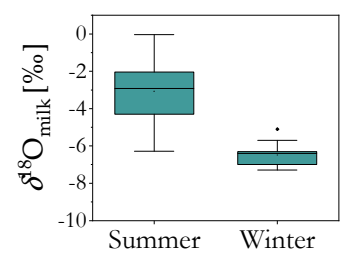

d)

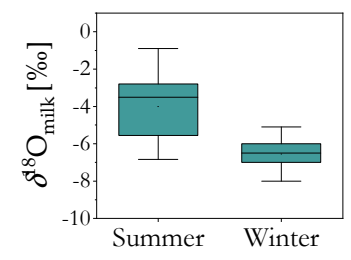

2013
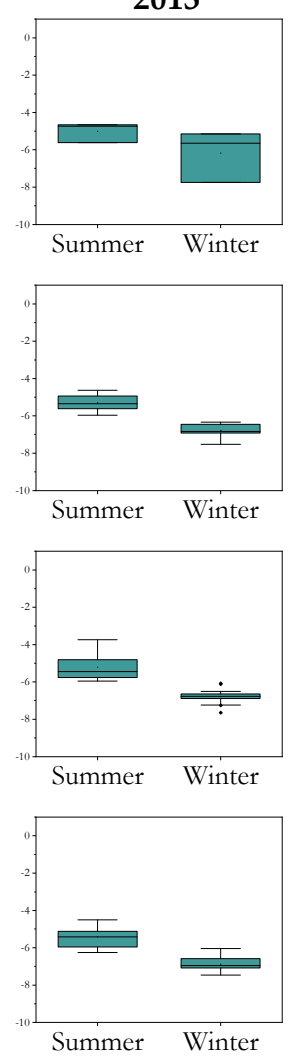

2014
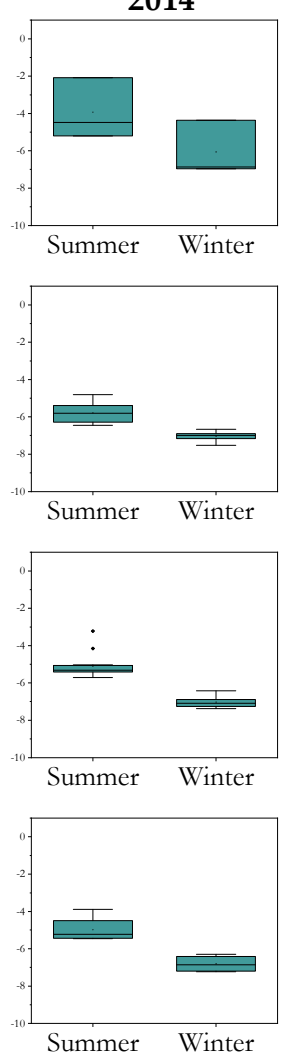

2015
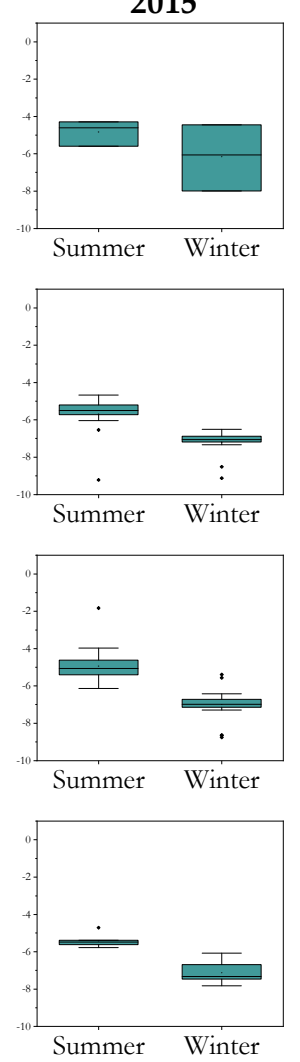

Figure 1. Box plots of the $\delta^{18} \mathrm{O}_{\text {milk }}$ values in cow milk collected from four macro-regions in Slovenia: (a) the Mediterranean, (b) Pannonian, (c) Alpine, (d) Dinaric region during summer and winter in 2012-2015. 
After applying an ANOVA test, significant differences $(p<0.05)$ in the $\delta^{18} \mathrm{O}_{\text {milk }}$ values according

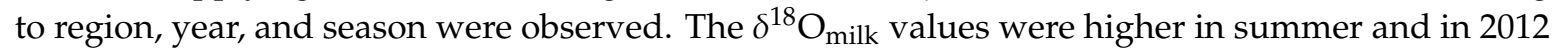
compared to 2013, 2014 and 2015. The results of the Tukey contrasts test $(p<0.05)$ indicate that the $\delta^{18} \mathrm{O}_{\text {milk }}$ values were the highest in the Mediterranean region, which out of the four regions has the mildest climate. Our findings are consistent with previous studies that show a seasonal variation in the $\delta^{18} \mathrm{O}$ values in milk water with higher ${ }^{18} \mathrm{O}$ content in the summer milk [32,34,36,37]. This increase results from the high evapotranspiration rate in fresh plant feed and animals during the summer. The use of water isotopes as an indicator of the geographical origin of milk is, however, only useful if the type of feed is known (i.e., fresh grass vs silage) [35], which unfortunately was not the case in our study.

From Figure 2, it is evident that the casein was ${ }^{18} \mathrm{O}$-enriched by approximately $17 \%$ relative to the milk water, and both $\delta^{2} \mathrm{H}_{\text {casein }}$ and $\delta^{18} \mathrm{O}_{\text {casein }}$ values were consistent, although their values varied slightly from region to region in 2014 (Figure 2; Table S1). No regional differences in

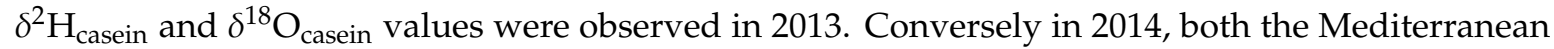
$\left(\delta^{18} \mathrm{O}_{\text {casein }}=12.8 \pm 1.3 \%\right.$ o $)$ and Pannonian $\left(\delta^{18} \mathrm{O}_{\text {casein }}=12.2 \pm 1.3 \%\right.$ o $)$ regions differ significantly from the Alpine $\left(\delta^{18} \mathrm{O}_{\text {casein }}=11.4 \pm 0.8 \%\right.$ o $)$ and Dinaric $\left(\delta^{18} \mathrm{O}_{\text {casein }}=11.2 \pm 0.7 \%\right.$ ones (Figure 2$)$. The highest $\delta^{18} \mathrm{O}_{\text {casein }}$ values were in milk produced at lower altitudes closer to the coast where the climate is dry and hot (Mediterranean region). Also, there were no significant regional differences in the average $\delta^{2} \mathrm{H}_{\text {casein }}$ values. It is interesting to note, that winter samples from the Dinaric region had a higher mean value $\delta^{2} \mathrm{H}_{\text {casein }}(-127 \%$ ) compared to the summer samples $(-134 \%$ o).
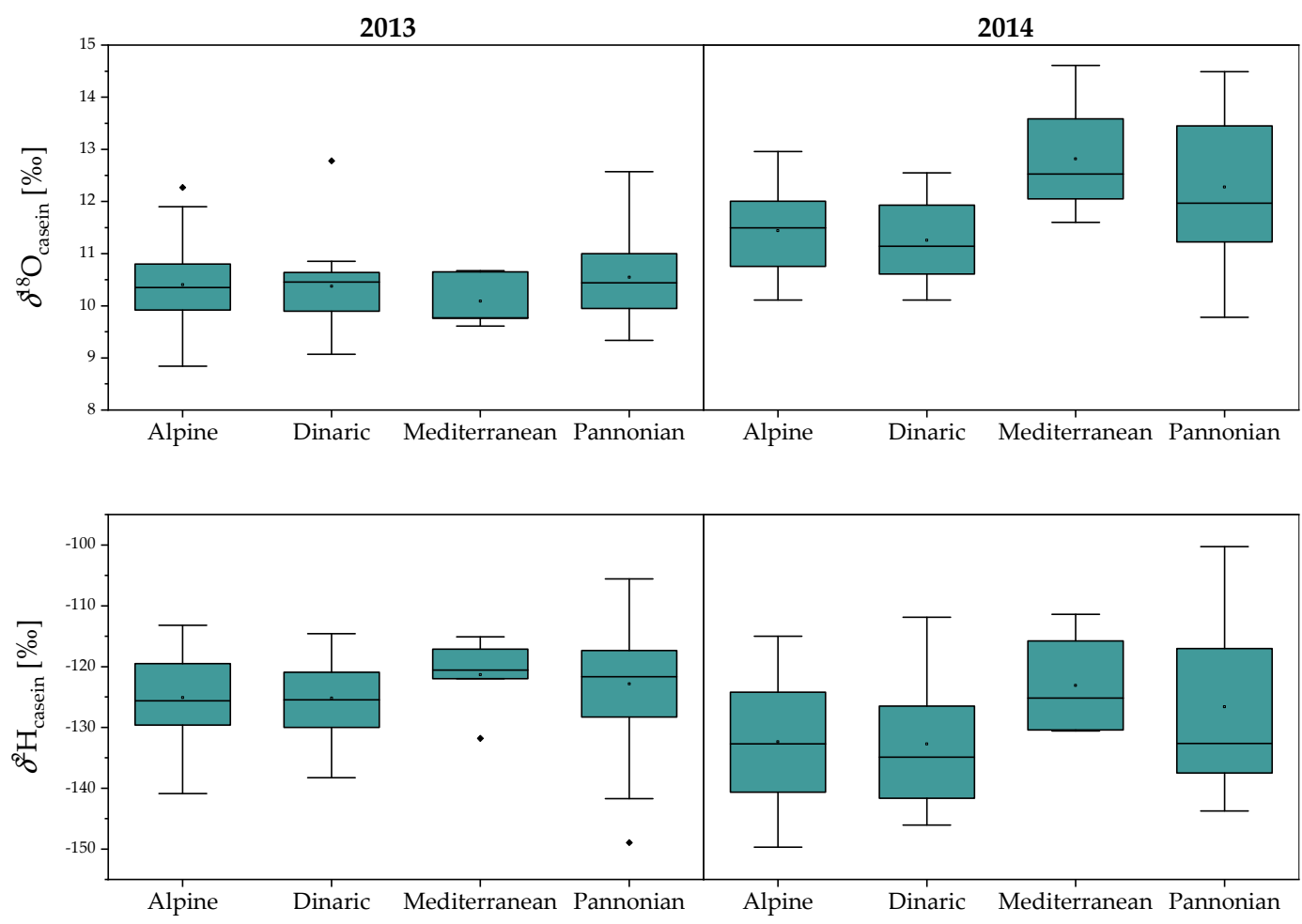

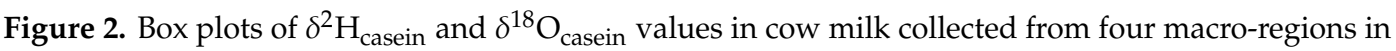
Slovenia in 2013 and 2014.

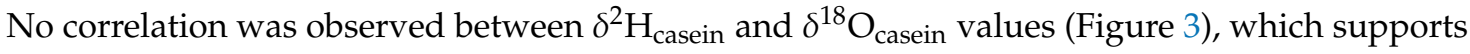
the finding from previous studies that $30 \%$ of the $\mathrm{H}$ and $70 \%$ of the $\mathrm{O}$ in milk protein derives from the local water, with the remaining fraction originating from the diet. Also, it is necessary to consider possible sources of variation related to isotopic fractionation in the animal's body water [29]. Similarly, the $\delta^{2} \mathrm{H}_{\text {casein }}$ values are influenced by the continuous exchange of ${ }^{2} \mathrm{H}$ between the animal's body water and drinking water in a specific location over time [30,31]. Thus, compared to the $\delta^{18} \mathrm{O}_{\text {milk values, }}$ 
$\delta^{18} \mathrm{O}_{\text {casein }}$ values provide a more consistent isotopic signature with which to determine the authenticity and origin of the milk.

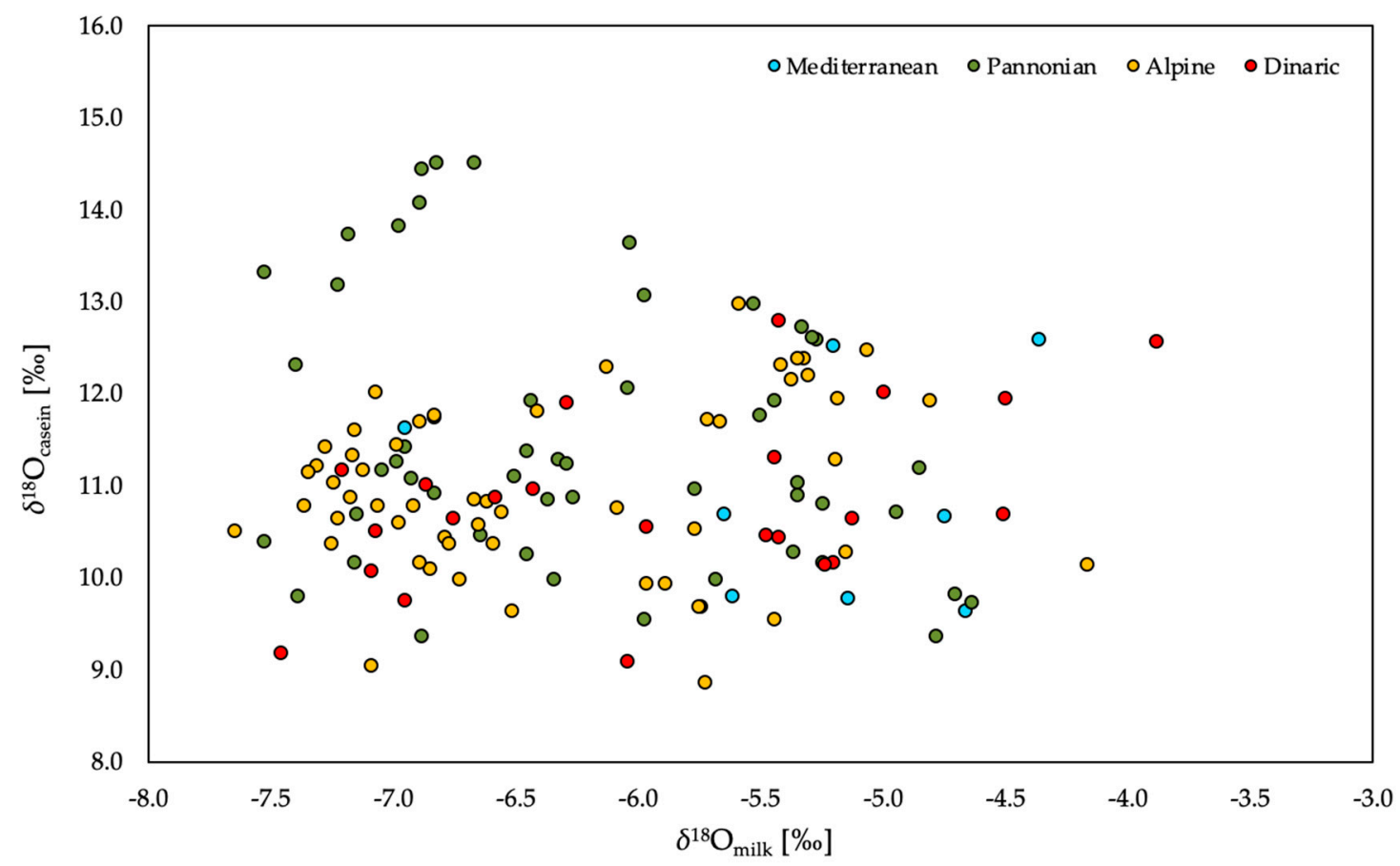

Figure 3. The relationship between $\delta^{18} \mathrm{O}_{\text {milk }}$ and $\delta^{18} \mathrm{O}_{\text {casein }}$ values in milk in relation to the region of production.

Given the interest in detecting commercial fraud of milk and dairy products, we determined the $\delta^{18} \mathrm{O}_{\text {milk }}$ values in cow, sheep and goat milk collected from farms located in Mediterranean region (Brkini, Vipava), Dinaric (Karst) and Alpine region (Bovec) from May to June in 2012 and 2013. The $\delta^{18} \mathrm{O}_{\text {milk }}$ values in goat, sheep and cow ranged from -3.6 to $2.4 \%$, from -5.6 to $1.2 \%$ ond from -6.6 to $-2.6 \%$, respectively.

It is evident from Figure 4 that $\delta^{18} \mathrm{O}_{\text {milk }}$ values in goat (average values: $\delta^{18} \mathrm{O}_{\text {milk }}=-0.9 \pm 2.1 \%$ o and $\delta^{18} \mathrm{O}_{\text {milk }}=-1.8 \pm 1.0 \%$ o, in 2012 and 2013, respectively) and sheep milk (average values: $\delta^{18} \mathrm{O}_{\text {milk }}=-2.4 \pm 1.6 \%$ o in 2012 and $\delta^{18} \mathrm{O}_{\text {milk }}=-3.1 \pm 1.6 \%$ o in 2013) are higher than the values in cow milk (average values: $\delta^{18} \mathrm{O}_{\text {milk }}=-3.0 \pm 0.5 \%$ o in 2012; $\delta^{18} \mathrm{O}_{\text {milk }}=-5.0 \pm 0.7 \%$ o in 2013). First, such differences could be related to the source of drinking water. Comparing to cows that predominantly drink groundwater, the sources of drinking water for goats and sheep are also rainwater and grazing on fresh pasture herbage that is enriched in ${ }^{18} \mathrm{O}$. Another explanation for the isotopic difference is animal physiology and diet. Bryant and Froelich [30] proposed that herbivore oxygen isotope composition in water body depends principally on body size. Total water flux (amount of water into and out of animals each day) also scale with body size but can be also influenced by dietary inputs and environmental temperature. Larger animals might on average be less capable to conserving water compared to smaller animals, however difference in water conservation depends also on water consumption. For example, goat drink water every few days, while cows must drink water every day [29]. Thus, it is expected that goat with lower water turnover rate have higher $\delta^{18} \mathrm{O}_{\text {milk }}$ values. Finally, because sweat, urine, and fecal water have higher $\delta^{18} \mathrm{O}$ values than water vapor, animals that pant to lose heat (goat, sheep), have high urinary salt concentrations, and have low fecal water contents, should have a higher $\delta^{18} \mathrm{O}_{\text {milk }}$ values than animals that lose more of their water as liquid (cow) $[27,29]$. 

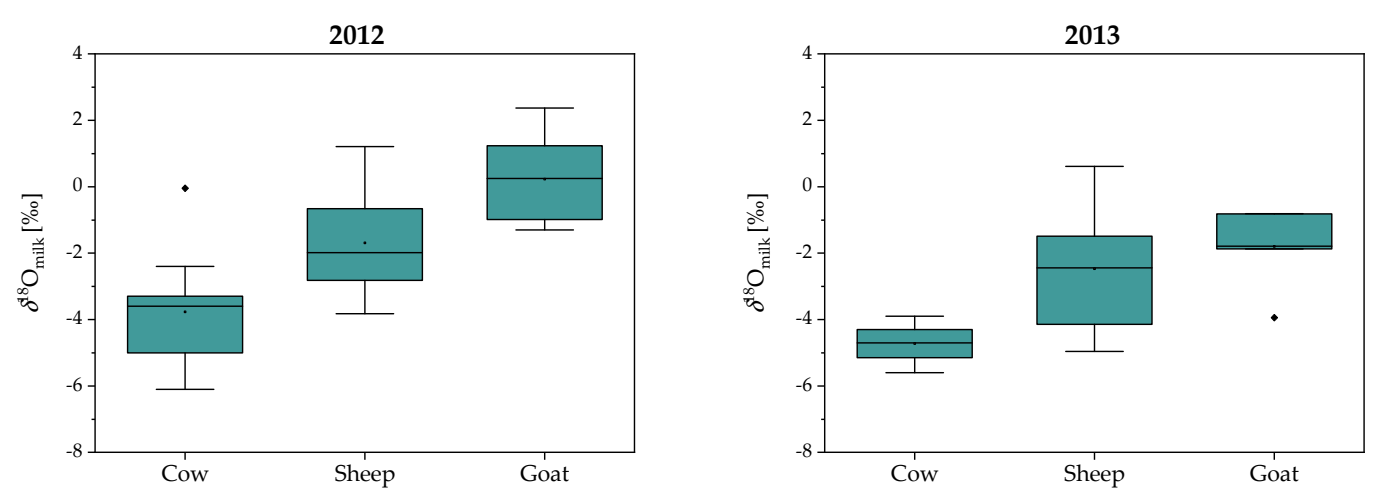

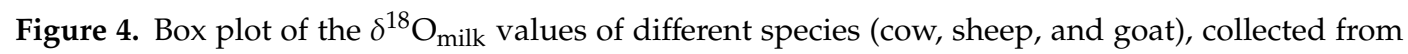
farms located in Mediterranean (Brkini, Vipava), Dinaric (Karst) and Alpine region (Bovec) in May and June in 2012 and 2013.

Further, $\delta^{18} \mathrm{O}_{\text {milk }}$ values in all three species are higher in 2012 comparing to 2013. One of the reasons could be unusual weather conditions in May and June in 2012 with extremely high temperatures (average: 14.1 and $20.6{ }^{\circ} \mathrm{C}$, respectively) comparing to 2013 (average: 13.5 and $18.2^{\circ} \mathrm{C}$, respectively) that can influence the source of water as well as activity level and body temperature regulation [35]. Rapid metabolism and more intense respiration also likely cause evaporative ${ }^{18} \mathrm{O}$-enrichment in body water. Lower $\delta^{18} \mathrm{O}_{\text {milk }}$ values were also observed in the Alpine region connected to higher altitude, lower temperatures and higher amount of precipitation.

\subsection{Stable Isotope Composition of Oxygen in Milk and Groundwater: Detection of Dilution with Water}

Overall, $\delta^{18} \mathrm{O}_{\text {milk }}$ values in milk depend on the sources of drinking water, metabolism, and isotopic fractionation during milk synthesis. In most cases, drinking water is taken from local groundwater (GW) sources, which reflects the isotopic composition of the mean annual precipitation [18]. For example, Liu et al. [38] found that $\delta^{2} \mathrm{H}$ and $\delta^{18} \mathrm{O}$ values in goat milk water were identical to that in drinking water. The $\delta^{2} \mathrm{H}$ and $\delta^{18} \mathrm{O}$ values of the water in cow milk correlate with geo-climatic characteristics of the area of origin, rather than dietary values [26]. Our data shows an ${ }^{18} \mathrm{O}$-enrichment of raw cow milk ranging from 1.0 to $6.6 \%$ relative to that in the drinking water dependent on the season. Garbaras et al. [39] report a variation from $1-8 \%$ o in the $\delta^{18} \mathrm{O}$ values between cow milk water and the drinking water. Ehtesham et al. [40] report an ${ }^{18} \mathrm{O}$-enrichment of approximately $4 \%$ o in milk water compared to farm water, but no significant correlation between the two variables was found. Kornexl et al. [32] report an ${ }^{18} \mathrm{O}$-enrichment of $2-6 \%$ o in milk water compared to ground water and other water sources.

There is usually no significant seasonal changes in $\delta^{18} \mathrm{O}$ values in groundwater $\left(\delta^{18} \mathrm{O}_{\mathrm{GW}}\right)$ due to its mean age typically covering decades to centuries. The distribution of the $\delta^{18} \mathrm{O}_{\mathrm{GW}}$ values together with the mean recharge rates in the whole Slovenia is presented by Mezga et al. [41]. The $\delta^{18} \mathrm{O}_{\mathrm{GW}}$ values of groundwater reported in our study ranged between $-9.1 \%$ o (Pannonian region) and $-6.7 \%$, (Mediterranean region) with an average standard deviation within one year of $0.5 \%$.

The monthly distribution of $\delta^{18} \mathrm{O}_{\text {milk }}$ values, together with $\delta^{18} \mathrm{O}_{\mathrm{GW}}$ values throughout the year 2012, is shown in Figure 5. The box plot of $\delta^{18} \mathrm{O}_{\text {milk }}$ values determined in June and December in 2013, 2014 and 2015 are also presented (Figure 5). Significant seasonal variations in the $\delta^{18} \mathrm{O}_{\text {milk }}$ values were observed, with higher values in summer days and lower values during winter. These findings support the fact that the water uptake by the cattle during the summer (at least in part) is from ingestion of fresh plants with water enriched in ${ }^{18} \mathrm{O}$ as a consequence of evapotranspiration in leaves [23]. As previously discussed, body water is also strongly affected by temperature, which is related to the primary function of water in the thermoregulation of an animal's body temperature [27]. A relationship between $\delta^{18} \mathrm{O}_{\text {milk }}$ and the season due to seasonal changes in the $\delta^{18} \mathrm{O}$ of forage plants, as well as in the body of the animal, linked to evapotranspiration was also reported by other studies $[32,34,36,39,40]$. 


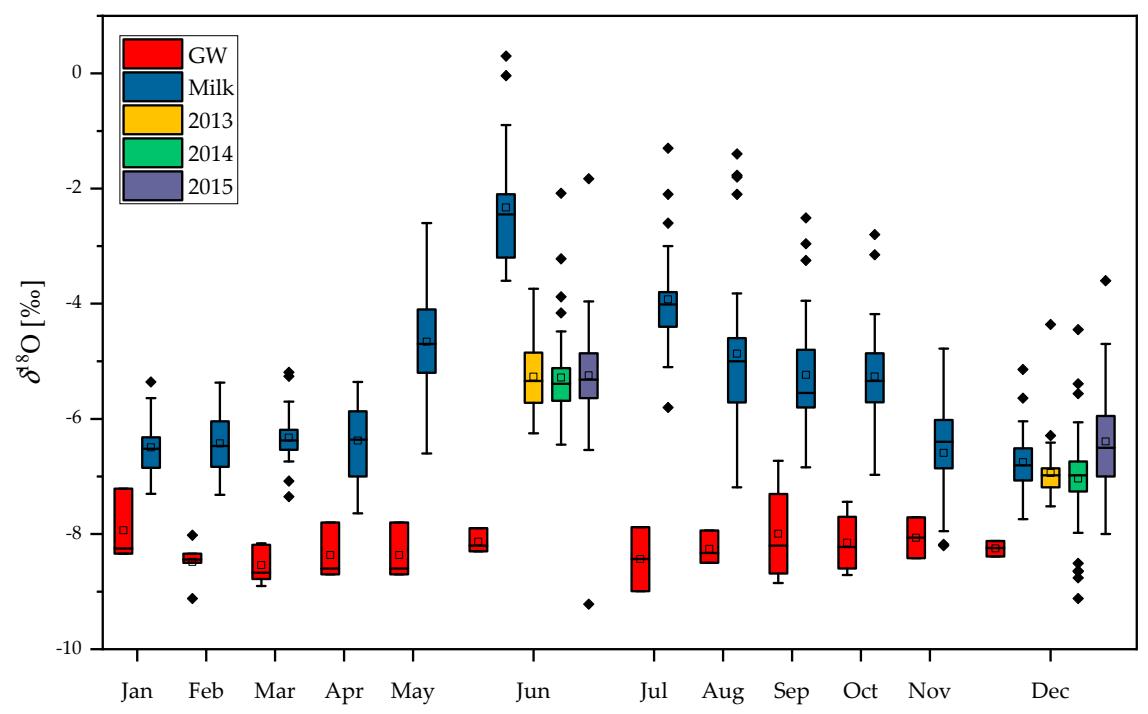

Figure 5. Seasonal variability in $\delta^{18} \mathrm{O}_{\text {milk }}$ and $\delta^{18} \mathrm{O}_{\mathrm{GW}}$ values in 2012. For comparison, the box plot of $\delta^{18} \mathrm{O}_{\text {milk }}$ values determined in June and December relative to the year (2013-2015) are presented on the graph. Data presented are taken for all regions in Slovenia.

The difference between the $\delta^{18} \mathrm{O}_{\text {milk }}$ and $\delta^{18} \mathrm{O}_{\mathrm{GW}}$ values indicated that based on the isotopic composition of oxygen, it is possible to detect the addition of water to milk, i.e., with a greater certainty during the summer period (Figure 5). A simple experiment was performed to evaluate the capability to detect milk dilution with water. For this experiment samples of milk and GW from four locations covering three different regions were collected in May 2017: Mediterranean (Ajdovščina),

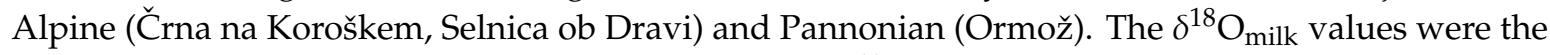
following $-7.4 \%$ o, $-6.0 \%$ o, $-6.5 \%$ o and $-5.6 \%$, while $\delta^{18} \mathrm{O}_{\mathrm{GW}}$ values were $-9.3 \%$ o, $-9.5 \%$ o, $-10.0 \%$ o and $-10.2 \%$, respectively. A serial of dilution of a raw (authentic) cow milk with drinking water in the following volume percentages: $0 \%, 1 \%, 3 \%, 5 \%, 7 \%, 10 \%, 15 \%, 20 \%$ and $30 \%$ was performed.

The results presented in Figure 6 show that diluting milk with varying amounts of water decreases the $\delta^{18} \mathrm{O}_{\text {milk }}$ values. The correlation coefficient between $\delta^{18} \mathrm{O}_{\text {milk }}$ values and added water was high $\left(\mathrm{R}^{2} \geq 0.89\right)$. Taking $2 \sigma$ from determination of $\delta^{18} \mathrm{O}_{\text {milk }}$ as a maximum acceptable difference between $\delta^{18} \mathrm{O}_{\text {milk }}$ values in authentic and diluted milk the addition of $>15 \%$ of water can be detected.

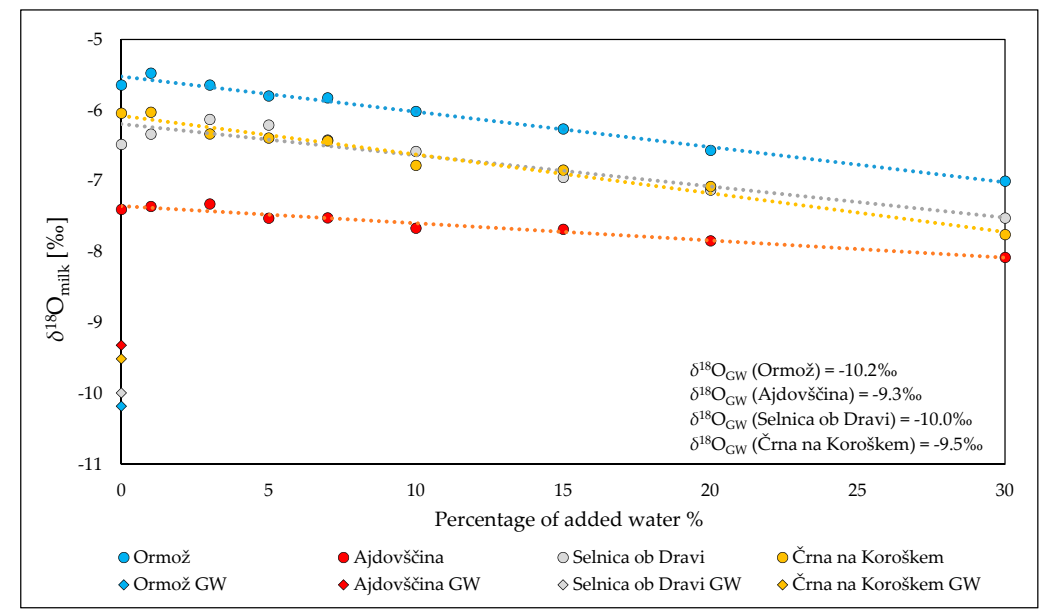

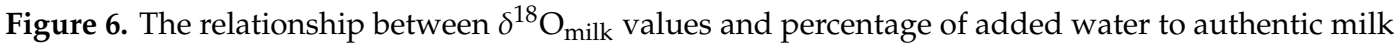
samples from different locations with different $\delta^{18} \mathrm{O}_{\mathrm{GW}}$. Measured $\delta^{18} \mathrm{O}_{\text {milk }}$ are significantly $(p<0.05)$ related to the $\delta^{18} \mathrm{O}_{\mathrm{GW}}$ in a regression analysis. The correlation coefficients between $\delta^{18} \mathrm{O}_{\text {milk values }}$ and added water were $0.98,0.89,0.98$ and 0.96 for Ormož, Selnica ob Dravi, Črna na Koroškem and Ajdovščina, respectively. 


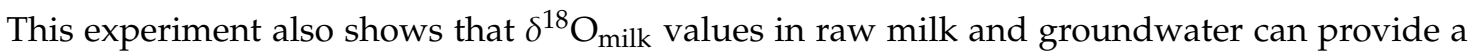
reference to detect adulteration and supports the findings of Lin et al. [42] who studied raw and manufactured milk from Taiwan. The method is more efficient than making cryoscopic measurements, especially when sodium chloride $(\mathrm{NaCl})$ is added, which is a common practice, together with water to milk. The addition of $\mathrm{NaCl}$ can decrease the freezing point of water in the milk, which means that the dilution of water with cryoscopic method cannot be detected.

\subsection{Lactose as an Internal Standard}

Further, we check if it is possible to improve the detection of water addition using lactose and $\delta^{18} \mathrm{O}_{\text {lactose }}$ values as internal standard, since there is a close relationship between lactose synthesis and the amount of water drawn into milk [43]. Based on the findings from the European project [44],

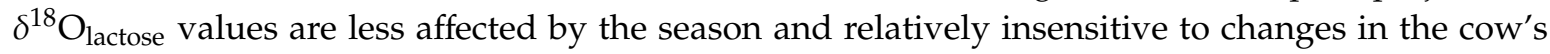
diet. The difference for organically bound oxygen in lactose between regions is less pronounced than for oxygen of water, as oxygen-containing lactose is produced continuously over a longer time and therefore scrambling or exchange may occur. Also, $\delta^{18} \mathrm{O}_{\text {lactose }}$ values are enriched by approximately $25 \%$ relative to the cattle feeding water (Figure 7 ). This increase is related to the plant cellulose breakdown by the cattle and the incorporation of its glucose oxygen into lactose during synthesis. By adding water, the $\delta^{18} \mathrm{O}_{\text {milk }}$ changes accordingly, whereas the value of lactose does not change. It means that if $\delta^{18} \mathrm{O}_{\text {lactose }}$ and $\delta^{18} \mathrm{O}_{\text {milk }}$ are correlated, addition of water eliminates this correlation

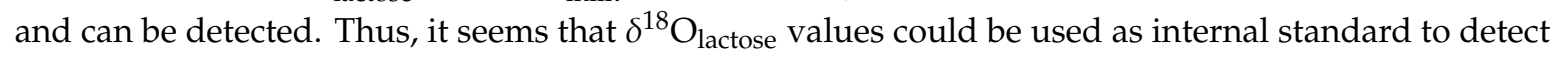
possible adulteration with water.

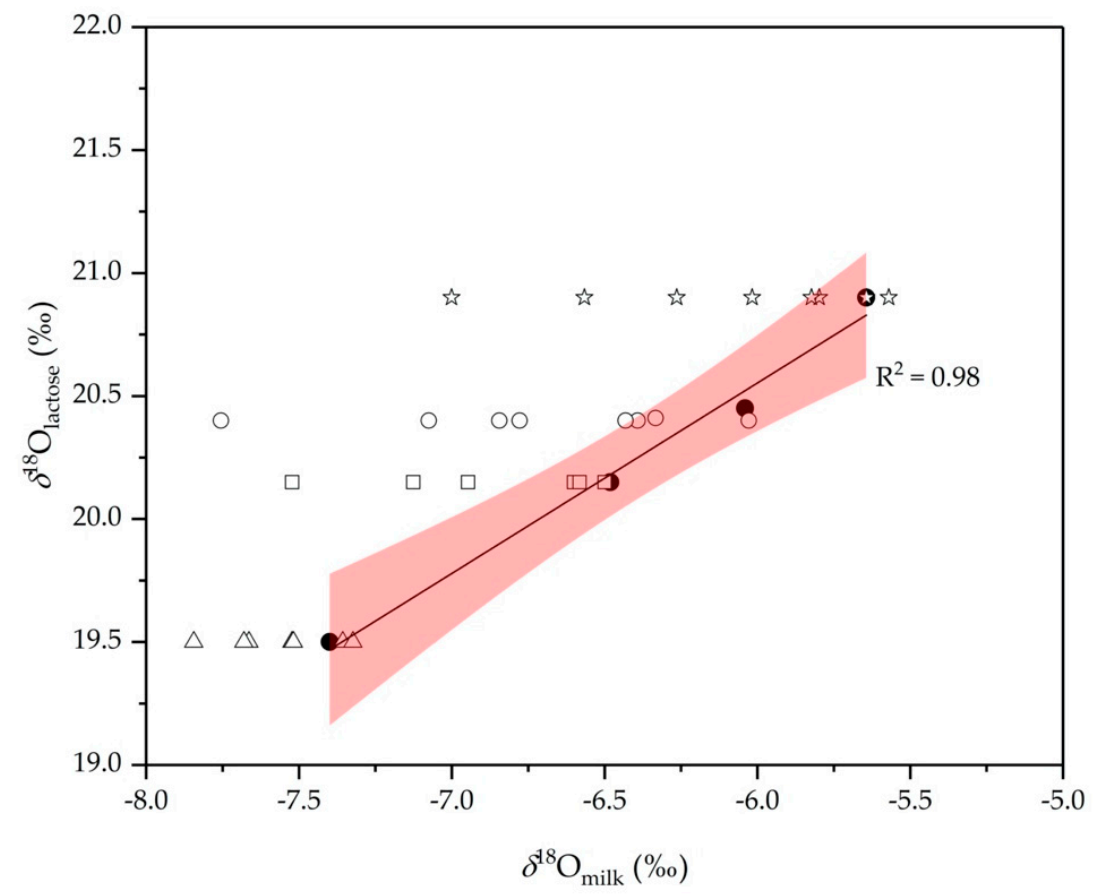

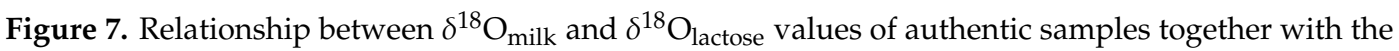
regression line and $95 \%$ of confidence levels $\left(R^{2}=0.98\right)$. The data for diluted milk from Ajdovščina, Črna na Koroškem, Selnica pri Dravi in Ormož are also included. From right to left, points show the $\delta^{18} \mathrm{O}_{\text {milk }}$ when adding $3 \%, 5 \%, 7 \%, 10 \%, 20 \%$ and $30 \%$ of water to milk.

To test this hypothesis, we prepared a series of diluted milk samples and determined their $\delta^{18} \mathrm{O}_{\text {lactose }}$ values. Authentic milk samples were collected from the same locations as the first experiment covering the typical $\delta^{18} \mathrm{O}_{\mathrm{GW}}$ values in Slovenia, to which $0 \%, 3 \%, 5 \%, 7 \%, 10 \%, 20 \%$ and $30 \%$ of water was added. The $\delta^{18} \mathrm{O}_{\text {lactose }}$ values for authentic samples ranged from $19.3 \%$ o to $20.8 \%$. The lowest $\delta^{18} \mathrm{O}$ values of lactose were determined for Ajdovščina and the highest for Ormož. These data are comparable 
with the data obtained in other EU countries, for example in France $\left(\delta^{18} \mathrm{O}_{\text {lactose }}=21.0 \pm 1.8 \%\right.$; $n=25)$, UK $\left(\delta^{18} \mathrm{O}_{\text {lactose }}=21.3 \pm 1.1 \% ; n=36\right)$, Italy $\left(\delta^{18} \mathrm{O}_{\text {lactose }}=16.8 \pm 3.1 \%\right.$; $\left.n=55\right)$, and Spain $\left(\delta^{18} \mathrm{O}_{\text {lactose }}=19.1 \pm 2.1 \% ; n=50\right)$, as reported in the final report of the European project [44].

The authenticity of the milk was evaluated by comparing the $\delta^{18} \mathrm{O}_{\text {lactose }}$ values with the corresponding $\delta^{18} \mathrm{O}_{\text {milk }}$ values of authentic and diluted milk samples. The results are presented

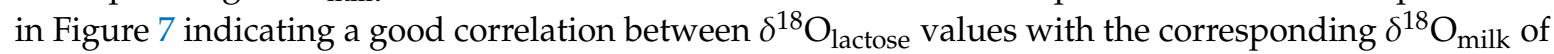
authentic samples $\left(\mathrm{R}^{2}=0.98\right)$. For diluted samples, $\delta^{18} \mathrm{O}_{\text {milk }}$ is not more correlated with $\delta^{18} \mathrm{O}_{\text {lactose }}$ and falls in most of the cases outside the $95 \%$ confidence level of the regression line. Although the number of results is limited and this must be interpreted with care, it appears that it is possible to detect the adulteration with water even at lower amounts of added water $(>7 \%)$. However, it should be pointed out that more research is needed on this topic especially since lactose, as the internal standard, may have its drawbacks in some cases. For example, higher measurement uncertainty is expected for milk with low lactose content.

\section{Materials and Methods}

\subsection{Sampling and Sample Preparation}

Authentic cow milk samples $(n=319)$ were collected directly from farms located in the four Slovenian macro-regions: Alpine, Dinaric, Pannonian, and the Mediterranean (Figure 8). The cow milk samples were obtained in summer (June) and winter (December) from 2013 to 2015. In 2012, samples of cow milk were collected monthly from January to December. In parallel, samples of groundwater $(\mathrm{GW})$ were also collected. In addition, samples of goat $(n=15)$ and sheep milk $(n=22)$ were collected systematically during May, June and July in 2012 and 2013 from Bovec (Alpine), Karst (Dinaric), Vipava and Brkini (Mediterranean), and central Slovenian region (Dinaric). All samples were frozen and stored at $-20^{\circ} \mathrm{C}$ prior to analysis.

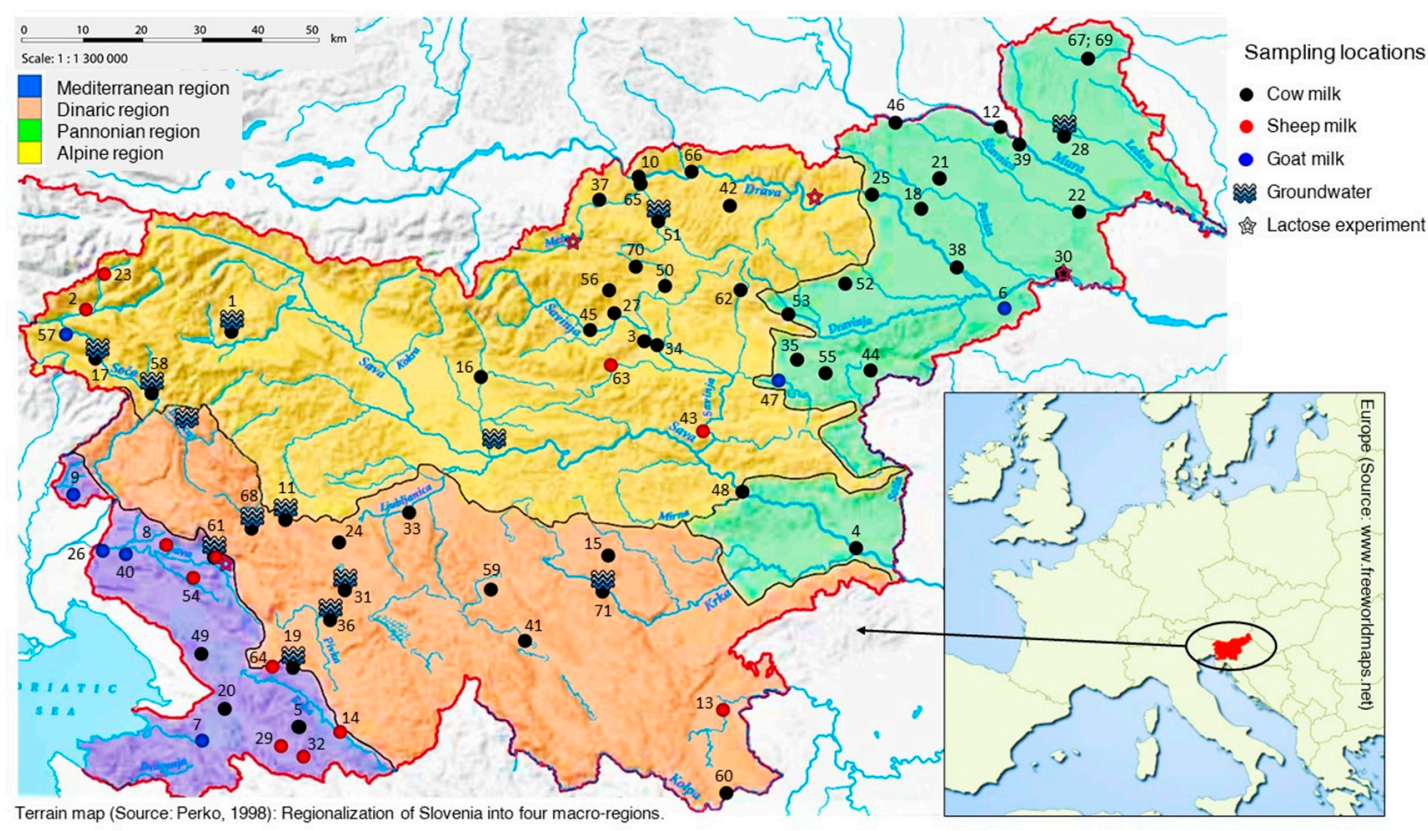

Figure 8. Macroregion division in Slovenia (after Perko, 1998) showing sampling locations of raw milk from different species covering geographical macro-regions (as indicated). The numbers correspond to the numbers of locations presented in Tables S1 and S2 (Supplement material). The locations used in experiments are also presented.

For pretesting the internal standardisation method, paired cow milk and drinking water samples from Alpine (Selnica ob Dravi, Črna na Koroškem), Mediterranean (Ajdovščina) and Pannonian 
(Ormož), were collected in May 2017. Samples were delivered with ice packs and then immediately registered and stored in the fridge upon receipt. All samples were stored at $4{ }^{\circ} \mathrm{C}$ for a period not exceeding $24 \mathrm{~h}$.

\subsection{Isolation of Casein}

Analytical preparation of milk samples was carried out according to the standard procedure [21]. Fat was removed from milk sample of $25 \mathrm{~mL}$ by centrifugation (Type Centric $322 \mathrm{~A}$, TEHTNICA, Železniki, Slovenia, $10 \mathrm{~min}$ at $3000 \times \mathrm{g}$ ) and the casein precipitated from the skimmed milk by acidification at $\mathrm{pH} 4.3$ with $2 \mathrm{~N} \mathrm{HCl}$ (CARLO ERBA, Val-de-Reuill, Loop, France) followed by subsequent centrifugation $(10 \mathrm{~min}$ at $3000 \times g)$. The precipitate was rinsed once with pure water (Milli-Q system, Millipore Sigma, Burlington, MA, USA) and once with petroleum ether:ether (2:1) (both Merck, Darmstadt, Germany). After the centrifugation, sample was heated in a water bath $\left(40^{\circ} \mathrm{C}\right)$ until solvent was completely removed, and then freeze-dried. In parallel, the supernatant fractions and the washing water were combined and used for the next step-isolation of lactose.

\subsection{Water Addition Experiment}

Two different experiments with water addition were prepared. First, we prepared a series of authentic raw cow milk samples $(\mathrm{V}=25 \mathrm{~mL})$ from four locations covering three different regions: Mediterranean (Ajdovščina), Alpine (Črna na Koroškem, Selnica ob Dravi) and Pannonian (Ormož). diluted with different proportions of drinking water $(0,1,3,5,7,10,15,20$ and $30 \% v / v)$. In this samples $\delta^{18} \mathrm{O}_{\mathrm{GW}}$ and $\delta^{18} \mathrm{O}_{\text {milk }}$ values were determined. In the second experiment, we also prepared a series of authentic cow milk samples $(\mathrm{V}=25 \mathrm{~mL}$ ) from the same locations diluted with different proportions of drinking water $(0,3,5,7,10,20$, and $30 \% v / v)$. In this experiment lactose was isolated and $\delta^{18} \mathrm{O}_{\text {milk }}$ values determined.

\subsection{Isolation of Lactose}

Lactose was obtained by heating the whey (supernatant) in a water bath $\left(80^{\circ} \mathrm{C}, 10 \mathrm{~min}\right)$ followed by filtration (Whatman 589/1, Sigma-Aldrich, St. Louis, MI, USA) and washing of the residue with not more than $5 \mathrm{~mL}$ of Milli-Q water [32]. The filtrate was then freeze-dried. Four replicates of each sample were prepared.

\subsection{Determination of Stable Hydrogen and Oxygen Isotope Ratios}

The determination of the stable of hydrogen and oxygen isotope ratios were performed using IRMS and expressed in the $\delta$-notation in \%o according to Equation (1) [45]:

$$
\delta^{\mathrm{i}} \mathrm{E}=\left(\mathrm{R}\left({ }^{\mathrm{i}} \mathrm{E} / \mathrm{E}\right)_{\text {sample }} / \mathrm{R}\left({ }^{\mathrm{i}} \mathrm{E} / \mathrm{E}\right)_{\text {standard }}\right)-1
$$

where $\mathrm{E}$ is the element $(\mathrm{H}, \mathrm{O}), \mathrm{R}$ is the isotope ratio between the heavier " $\mathrm{i}$ " and the lighter " $\mathrm{j}$ " isotope $\left({ }^{2} \mathrm{H} /{ }^{1} \mathrm{H},{ }^{18} \mathrm{O} /{ }^{16} \mathrm{O}\right)$ in the sample and relevant internationally recognised reference standard. The delta values are multiplied by 1000 and expressed in units "per mil" (\%o).The $\delta^{2} \mathrm{H}$ and $\delta^{18} \mathrm{O}$ were reported relative to the Vienna-Standard Mean Ocean Water (V-SMOW) standard [45].

The $\delta^{18} \mathrm{O}_{\text {milk }}$ and $\delta^{18} \mathrm{O}_{\mathrm{GW}}$ values were determined directly in milk and water after equilibration with reference gas $\mathrm{CO}_{2} / \mathrm{He}\left(5 \% \mathrm{CO}_{2}\right)$ at $40{ }^{\circ} \mathrm{C}$ for $6 \mathrm{~h}$. Measurements were performed on a continuous flow IRMS (GV Instruments ltd, Manchester, UK) connected with MultiFlow Bio preparation system (IsoPrime, GV Instruments Itd, Manchester, UK). The results for milk water were normalised against the following laboratory standards: W-3869 (seawater $\delta^{18} \mathrm{O}_{\text {VSMOW-SLAP }}=0.36 \pm 0.04 \%$ ) and W-3871 (snow water; $\delta^{18} \mathrm{O}_{\mathrm{VSMOW}-S L A P}=-19.73 \pm 0.02 \%$ ). An independent laboratory reference material $\mathrm{W}-3870$ (Mili-Q water, $\delta^{18} \mathrm{O}_{\mathrm{VSMOW}-\mathrm{SLAP}}=-9.12 \pm 0.04 \%$ o) was analysed periodically throughout the sequence as a control to ensure the quality of the results. The laboratory standards used are calibrated against certified reference materials: NIST 8535a- (Vienna Standard Mean Ocean 
Water 2; IAEA-VSMOW2) (water; $\delta^{18} \mathrm{O}_{\text {VSMOW-SLAP }}=0.00 \pm 0.02 \%$ o), RM 8537a- (Standard Light Antarctic Precipitation water; IAEA-SLAP2 $)\left(\delta^{18} \mathrm{O}_{\text {VSMOW-SLAP }}=-55.50 \pm 0.02 \%\right.$ o $)$ and NIST RM 8536 (Greenland Ice Sheet Precipitation water; GISP) $\left(\delta^{18} \mathrm{O}_{\text {VSMOW-SLAP }}=-24.76 \pm 0.09 \%\right.$ o). For each set of measurement, laboratory reference materials (W-3869 and W-3871) for normalization were measured four times; two times at the beginning of the batch, and two times at the end of the batch, while the control material (W-3870; MiliQ water) was measured six times; at the beginning, in the middle and at the end of the batch. Measurements precision was $0.1 \%$ o for $\delta^{18} \mathrm{O}$ and $1 \%$ o for $\delta^{2} \mathrm{H}$.

The ${ }^{2} \mathrm{H} /{ }^{1} \mathrm{H}$ and ${ }^{18} \mathrm{O} /{ }^{16} \mathrm{O}$ and measurements of lactose and casein were performed at the Department of Food Quality and Nutrition, Research and Innovation Centre, Fondazione Edmund Mach in San Michele all' Adige, Italy. The $\delta^{2} \mathrm{H}$ and $\delta^{18} \mathrm{O}$ values of lactose $\left(\delta^{2} \mathrm{H}_{\text {lactose, }} \delta^{18} \mathrm{O}_{\text {lactose }}\right)$ and casein $\left(\delta^{2} \mathrm{H}_{\text {casein }}, \delta^{18} \mathrm{O}_{\text {casein }}\right)$ were determined by transferring of freeze-dried samples, respectively, into a silver capsule and analysing the sample simultaneously using TC/EA pyrolyser (Thermo Finnigan, Waltham, MA, USA) coupled to a DELTA XP isotope ratio-mass spectrometer, IRMS (Thermo Scientific, Waltham, MA, USA). For normalisation of the results, two internal laboratory reference materials were applied: Caribou Hoof Standard (CBS) and Kudu Horn Standard (KHS). The sample weight was $0.2 \mathrm{mg}$ and $0.4 \mathrm{mg}$ for lactose and casein, respectively. The results for lactose and casein were calibrated against the following international reference materials: CBS keratin (Caribou Hoof Standard; $\delta^{2} \mathrm{H}_{\text {VSMOW-SLAP }}=-157.0 \pm 0.9 \%$ o, $\delta^{18} \mathrm{O}_{\text {VSMOW-SLAP }}=+3.8 \pm 0.3 \%$ o $)$ and KHS keratin (Kudu Horn Standard; $\delta^{2} \mathrm{H}_{\text {VSMOW-SLAP }}=-35.3 \pm 1.1 \%$ o, $\delta^{18} \mathrm{O}_{\text {VSMOW-SLAP }}=+20.3 \pm 0.3 \%$ o). Measurements precision was $\pm 0.2 \%$ o for $\delta^{18} \mathrm{O}$ and $\pm 1 \%$ o for $\delta^{2} \mathrm{H}$.

Data quality control charts were systematically recorded throughout the study period. To ensure the validity and comparability of the isotope results, the laboratory regularly participates in the Food analysis using Isotopic Techniques-Proficiency Testing Scheme FIT-PTS organized by EUROFINS (Nantes, France) three times per year. In this scheme, water and casein are also included.

\subsection{Statistical Analysis}

The data was processed using the statistical software package OriginPro 2018 (OriginLab, MicroCal Inc., Harrisburg, PE, USA), and Microsoft Excel (Microsoft Office Professional Plus 2019, Microsoft Corporation, Redmond, WA, USA). The existence of differences was verified through representation of variables within numeric data with box-plots (which graphically display summary of a data set: median, minimum, and maximum) or through regression analysis at a confidence level of $95 \%$. One-way ANOVA was performed to determine the significant temporal (season, year) and spatial difference of variables. In the statistical test probability $(p)$ values of less than 0.05 were used to indicate a significance level. If the significance was noted in a response factor, the calculation was followed by post-hoc testing using the Tukey's Honestly Significant Difference (HSD) test.

\section{Conclusions}

This study demonstrated that by using the stable isotope composition of oxygen in milk water it is possible to discriminate milk from Slovenia according to the season and animal species, while regional discrimination is limited. The compositional differences in animal species indicate that diet and physiology have a strong control on animal isotope composition of body water and consequently also to milk. Seasonal variation in $\delta^{18} \mathrm{O}_{\text {milk }}$ values are controlled by evaporation processes. Actually, the "evaporation effect" may be related directly to the animal physiology as well as to ingestion of fresh grass with water enriched in ${ }^{18} \mathrm{O}$ as a consequence of evapotranspiration in leaves. No significant statistical differences in $\delta^{2} \mathrm{H}_{\text {casein }}$ and $\delta^{18} \mathrm{O}_{\text {casein }}$ values according to the season and region of milk production was observed indicating that these two parameters provide more consistent isotopic signature with which to access the authenticity and origin of the milk. Further, the milk water is remarkably enriched in ${ }^{18} \mathrm{O}$ compared to groundwater providing a possibility to detect addition of water. Based on our experiment it was found that $>15 \%$ of added water can be detected by determining $\delta^{18} \mathrm{O}_{\text {milk }}$ and $\delta^{18} \mathrm{O}_{\mathrm{GW}}$ values. The method using $\delta^{18} \mathrm{O}_{\text {lactose }}$ values as an internal standard was shown 
to be even more promising in improving the detection of the illegal watering of milk ( $>7 \%)$. A further improvement of this approach could be made in the future by analyzing higher number of samples originating from different countries.

Supplementary Materials: The following are available online. Table S1: Geographical information of the sampling location together with $\delta^{18} \mathrm{O}_{\text {milk}}, \delta^{18} \mathrm{O}_{\text {casein }}$ and $\delta^{2} \mathrm{H}_{\text {casein }}$ values during the summer and winter in the year period from 2012 to 2015; Table S2: Data collection of the $\delta^{18} \mathrm{O}$ values of milk of different dairy species: sheep and goat. For comparison, samples were collected during summer season from May to June in 2012 and 2013.

Author Contributions: Conceptualization, S.H.G. and N.O.; Methodology, D.P., F.C.; Validation, S.H.G., D.P. and F.C.; Formal analysis, S.H.G. and D.P.; Investigation, S.H.G. and N.O.; Resources, N.O.; Data curation, S.H.G.; Writing — original draft preparation, S.H.G.; Writing_-review and editing, N.O.; Visualization, S.H.G.; Supervision, N.O. All authors have read and agreed to the published version of the manuscript.

Funding: The work was performed within IAEA project "The use of stable isotopes and elemental composition for determination of authenticity and geographical origin of milk and dairy products" (Contract No. 17897). This research represents a part of the ERA Chair ISO-FOOD for isotope techniques in food quality, safety, and traceability (FP7, GA no. 621329) and MASSTWIN-Spreading excellence and widening participation in support of mass spectrometry and related techniques in health, the environment and food analysis (H2020, GA no. 692241).

Acknowledgments: We thank Ljubljanske mlekarne, d.d., Pomurske mlekarne, d.d., Mlekarna Vipava d.d., Mlekarna Planika predelava mleka d.o.o., and Mlekarna Celeia for supplying monthly authentic cow milk samples and Kmetijski gozdarski zavod Nova Gorica for supplying goat and sheep milk. The authors also thank all local producers of goat and sheep milk for providing the samples.

Conflicts of Interest: The authors declare no conflict of interest.

\section{References}

1. Kamal, M.; Karoui, R. Analytical methods coupled with chemometric tools for determining the authenticity and detecting the adulteration of dairy products: A review. Trends. Food Sci. Technol. 2015, 46, 27-48. [CrossRef]

2. Handford, C.E.; Campbell, K.; Elliott, C.T. Impacts of Milk Fraud on Food Safety and Nutrition with Special Emphasis on Developing Countries: Health impacts of milk fraud. Com. Rev. Food Sci. Food Saf. 2016, 15, 130-142. [CrossRef]

3. De La Fuente, M.A.; Juárez, M. Authenticity Assessment of Dairy Products. Crit. Rev. Food Sci. Nut. 2005, 45, 563-585. [CrossRef] [PubMed]

4. Azad, T.; Ahmed, S. Common milk adulteration and their detection techniques. Food Contam. 2016, 3, 2. [CrossRef]

5. Santos, P.M.; Pereira-Filho, E.R.; Rodriguez-Saona, L.E. Rapid detection and quantification of milk adulteration using infrared microspectroscopy and chemometrics analysis. Food Chem. 2013, 138, 19-24. [CrossRef]

6. Musara, C.; Pote, W. Application of osmometry in quality analysis of milk. J. Food Sci. Technol. 2014, 51, 606-610. [CrossRef]

7. Vujadinović, D.; Beribaka, M.; Vukić, M.; Marjanović-Balaban, Ž. Comparison of methods for determining the falsification of milk. J. Hyg. Engin. Des. 2017, 18, 19-24.

8. Qu, J.-H. Applications of near-infrared spectroscopy in food safety evaluation and control: A review of recent research advances. Crit. Rev. Food Sci. Nutr. 2015, 55, 1939-1954. [CrossRef]

9. Kasemsumran, S.; Thanapase, W.; Kiatsoonthon, A. Feasibility of Near-Infrared Spectroscopy to detect and to quantify adulterants in cow milk. Anal. Sci. 2007, 23, 907-910. [CrossRef]

10. Büning-Pfaue, H. Analysis of water in food by near infrared spectroscopy. Food Chem. 2003, 82, 107-115. [CrossRef]

11. Pedretti, N.; Bertrand, D.; Semenou, M.; Robert, P.; Giangiacomo, R. Application of an experimental design to the detection of foreign substances in milk. J. Near Infra Spectrosc. 1993, 1, 174-184. [CrossRef]

12. Castell-Palou, A.; Rosselló, C.; Femenia, A.; Simal, S. Simultaneous quantification of fat and water content in cheese by TD-NMR. Food Bioprocess. Technol. 2012, 6, 2685-2694. [CrossRef]

13. Santos, P.M.; Pereira-Filho, E.R.; Colnago, L.A. Detection and quantification of milk adulteration using time domain nuclear magnetic resonance (TD-NMR). Microchem. J. 2016, 124, 15-19. [CrossRef]

14. Danezis, G.P.; Tsagkaris, A.S.; Camin, F.; Brusic, V.; Georgiou, C.A. Food authentication: Techniques, trends \& emerging approaches. TrAC-Trends Anal. Chem. 2016, 85, 123-132. [CrossRef] 
15. Dordevic, N.; Camin, F.; Marianella, R.M.; Postma, G.J.; Buydens, L.M.C.; Wehrens, R. Detecting the addition of sugar and water to wine: Detecting the addition of sugar and water to wine. Aust. J. Grape Wine Res. 2013, 19, 324-330. [CrossRef]

16. Calderone, G.C.; Guillou, C. Analysis of isotopic ratios for the detection of illegal watering of beverages. Food Chem. 2008, 106, 1399-1405. [CrossRef]

17. Meier-Augenstein, W.; Kemp, H.F.; Hardie, S.M.L. Detection of counterfeit scotch whisky by ${ }^{2} \mathrm{H}$ and ${ }^{18} \mathrm{O}$ stable isotope analysis. Food Chem. 2012, 133, 1070-1074. [CrossRef]

18. Dansgaard, W. Stable isotopes in precipitation. Tellus 1964, 16, 436-468. [CrossRef]

19. Gat, J.R. Oxygen and hydrogen isotopes in the hydrological cycle. Ann. Rev. Earth Plan. Sci. 1996, 24, 225-262. [CrossRef]

20. Clark, I.D.; Fritz, P. Environmental Isotopes in Hydrogeology; CRC Press: London, UK, 1997.

21. Craig, H. Isotopic Variations in Meteoric Waters. Science 1961, 133, 1702-1703. [CrossRef]

22. Hobson, K.A.; Koehler, G. On the use of stable oxygen isotope $(\delta(18) \mathrm{O})$ measurements for tracking avian movements in North America. Ecol. Evol. 2015, 5, 799-806. [CrossRef] [PubMed]

23. Barbour, M.M. Stable oxygen isotope composition in plant tissue: A review. Funct. Plant. Biol. 2007, 34, 83-94. [CrossRef]

24. Schmidt, H.-L.; Werner, R.A.; Roûmann, A. ${ }^{18} \mathrm{O}$ Pattern and biosynthesis of natural plant products. Phytochem 2001, 58, 9-32. [CrossRef]

25. Krivachy (Tanz), N.; Rossmann, A.; Schmidt, H.L. Potentials and caveats with oxygen and sulfur stable isotope analyses in authenticity and origin checks of food and food commodities. Food Cont. 2015, 48, 143-150. [CrossRef]

26. Camin, F.; Perini, M.; Colombari, G.; Bontempo, L.; Versini, G. Influence of dietary composition on the carbon, nitrogen, oxygen and hydrogen stable isotope ratios of milk. Rapid Commun. Mass Spectrom. 2008, 22, 1690-1696. [CrossRef] [PubMed]

27. Abeni, F.; Petrera, F.; Capelletti, M.; Dal Prà, A.; Bontempo, L.; Tonon, A. Hydrogen and oxygen stable isotope fractionation in body fluid compartments of dairy cattle according to season, farm, breed, and reproductive stage. PLoS ONE 2015, 10, e0127391. [CrossRef] [PubMed]

28. Kohn, M.J. Predicting animal $\delta^{18} \mathrm{O}$ : Accounting for diet and physiological adaptation. Geochim. Cosmochim. Acta 1996, 60, n4811-n4829. [CrossRef]

29. Kohn, M.J.; Schoeninger, M.J.; Valley, J.W. Herbivore tooth oxygen isotope compositions: Effects of diet and physiology. Geochim. Cosmochim. Acta 1996, 60, 3889-3896. [CrossRef]

30. Bryant, D.; Froelich, P.N. A model of oxygen isotope fractionation in body water of large mammals. Geochim. Cosmochim. Acta 1995, 59, 4523-4537. [CrossRef]

31. Podlesak, D.W.; Torregrossa, A.-M.; Ehleringer, J.R.; Dearing, M.D.; Passey, B.H.; Cerling, T.E. Turnover of oxygen and hydrogen isotopes in the body water, $\mathrm{CO}_{2}$, hair, and enamel of a small mammal. Geochim. Cosmochim. Acta 2008, 72, 19-35. [CrossRef]

32. Kornexl, B.E.; Werner, T.; Roßmann, A.; Schmidt, H.-L. Measurement of stable isotope abundances in milk and milk ingredients-A possible tool for origin assignment and quality control. Z. Für Lebensm. Und Forsch. A 1997, 205, 19-24. [CrossRef]

33. Chesson, L.A.; Valenzuela, L.O.; O'Grady, S.P.; Cerling, T.E.; Ehleringer, J.R. Hydrogen and oxygen stable isotope ratios of milk in the United States. J. Agric. Food Chem. 2010, 58, 2358-2363. [CrossRef] [PubMed]

34. Crittenden, R.G.; Andrew, A.S.; LeFournour, M.; Young, M.D.; Middleton, H.; Stockmann, R. Determining the geographic origin of milk in Australasia using multi-element stable isotope ratio analysis. Int. Dairy J. 2007, 17, 421-428. [CrossRef]

35. Vander Zanden, H.B.; Soto, D.X.; Bowen, G.J.; Hobson, K.A. Expanding the isotopic toolbox: Applications of hydrogen and oxygen stable isotope ratios to food web studies. Front. Ecol. Evol. 2016, 4, 20. [CrossRef]

36. Magdas, D.A.; Cristea, G.; Cordea, D.V.; Bot, A.; Puscas, R.; Radu, S.; Mirel, V.; Mihaiu, M. Measurements of Stable Isotope Ratios in Milk Samples from a Farm Placed in the Mountains of Transylvania. In AIP Conference Proceedings, Proceedings of the Isotopes and Molecules (PIM 2013), Cluj Napoca, Romania, 25-27 September 2013; American Institute of Physics: University Park, MD, USA, 2013.

37. Chung, I.-M.; Kim, J.K.; Yang, Y.J.; An, Y.J.; Kim, S.Y.; Kwon, C.; Kim, S.H. A case study for geographical indication of organic milk in Korea using stable isotope ratios-based chemometric analysis. Food Cont. 2020, 107, 106755. [CrossRef] 
38. Liu, H.; Zhao, Q.; Guo, X.; Tang, C.; Yu, X.; Zhan, T.; Qin, Y.; Zhang, J. Application of isotopic and elemental fingerprints in identifying the geographical origin of goat milk in China. Food Chem. 2019, 277, 448-454. [CrossRef]

39. Garbaras, A.; Skipityte, R.; Šapolaitè, J.; Ežerinskis, Ž.; Remeikis, V. Seasonal variation in stable isotope ratios of cow milk in Vilnius region, Lithuania. Animals 2019, 9, 69. [CrossRef]

40. Ehtesham, E.; Hayman, A.; Van Hale, R.; Frew, R. Influence of feed and water on the stable isotopic composition of dairy milk. Int. Dairy J. 2015, 47, 37-45. [CrossRef]

41. Mezga, K.; Urbanc, J.; Cerar, S. The isotope altitude effect reflected in groundwater: A case study from Slovenia. Isot. Env. Health Stud. 2014, 50, 33-51. [CrossRef]

42. Lin, G.P.; Rau, Y.H.; Chen, Y.F.; Chou, C.C.; Fu, W.G. Measurements of $\delta \mathrm{D}$ and $\delta^{18} \mathrm{O}$ stable isotope ratios in milk". J. Food Sci. 2003, 68, 2192-2195. [CrossRef]

43. Golc-Teger, S. "Sadržaj laktoze kao indikator dodate vode u mleku. Mljekarstvo 1985, 37, 195-204.

44. SMT4-CT98-2236 (EU project): The Development and Validation of Methods to Determine the Origin of Milk, Butter and Cheese; Central Science Laboratory; Final Report; December 2001. Available online: https: //www.bats.ch/trace/?file5=coreforms/organisation.php\&record_number=1 (accessed on 31 December 2001).

45. Brand, W.A.; Coplen, T.B.; Vogl, J.; Rosner, M.; Prohaska, T. Assessment of international reference materials for isotope-ratio analysis (IUPAC technical report). Pure Appl. Chem. 2014, 86, 425-467. [CrossRef]

Sample Availability: not available. 